\title{
Impact Analysis of an Innovative Extraction Process for Ndjansang (Ricinodendron heudelotii) Seeds on the Welfare of Local Producers in Nyong and Mfoumou Division, Cameroon
}

\author{
Biloa Tsanga Florence ${ }^{1}$, Kaldjob Mbeh Christian Bernard ${ }^{1,2 *}$, Nso Ngang André2, \\ Minkoua Nzie Jules Rene ${ }^{3}$ and Awono Abdon ${ }^{4}$ \\ ${ }^{1}$ University of Yaounde II Soa, PO: 14023, Yaounde, Cameroon \\ ${ }^{2}$ Institute of Agricultural Research for Development (IRAD), PO 2123, Yaounde, Cameroun \\ ${ }^{3}$ University of Buea, PO: 63 Buea Cameroon \\ ${ }^{4}$ Center for International Forestry Research (CIFOR) PO BOX 2008, Yaounde, Cameroon
}

"Corresponding author: christianbernard.kaldjob@yahoo.fr (ORCID ID: 0000-0003-2461-2135)

Paper No. 935

Received: 19-05-2021

Revised: 09-07-2021

Accepted: 07-08-2021

\begin{abstract}
Ndjansang is a non-timber forest product (NTFP) that is part of the traditional medicinal, cosmetic and gastronomic practices of populations in sub-Saharan Africa. Although its price has increased considerably in recent years, making it an essential source of income for farming households, its production level remains low due to the arduous extraction of almonds, making the production process laborious and burdensome. The introduction of innovation such as the almond crushing machine to ease hired conditions and improve the welfare of producers seems indispensable. Therefore, this article assesses the impact of the adoption of this innovation on producers' income in Cameroon's central region. The non-experimental method of assessing impact using propensity scores was used on a sample of 216 producers selected in a reasoned manner. The results reveal that producers who adopted the innovation in the production process experienced a considerable increase in their income per kilogram in Ndjansang (US\$ 0.16 per kg) with a statistically positive and significant effect of $1 \%$, compared to manual production. Seed quality has also been greatly improved, as some manually ground almonds have been broken or transported under dangerous conditions. This allows producers to spend more time on other income-generating activities. Variables such as membership of the farmer organization, quantities produced, household size, and the Ndjansang bowl price are the main determinants of the adoption of this innovation. Indeed, the farmer organization's membership is an essential factor in adoption because the producer who is enrolled in a farmer organization can have access to more innovations, information, resources, and training. In order to ensure sustainable income and welfare for producers, it is then essential to introduce and disseminate this innovation through value-adding policies in the Ndjansang value chain.
\end{abstract}

\section{HIGHLIGHTS}

(0 The extraction of this product is very laborious, as it requires large quantities of seeds for little oil. This difficulty is characterized by the lack of agricultural innovations such as crushing machines for some rural producers.

(0 The crushing machine introduced here in each intervention village is a technological innovation that consists of the mechanization of the crushing process. With a value of US $\$ 3500$, its production capacity used in an optimal way ( 8 hours/day) is $600 \mathrm{Kg}$.

(0 The producers who adopted the innovation in the production process experienced a considerable increase in their income per kilogram in Ndjansang (US\$ 0.16 per $\mathrm{kg}$ ) with a statistically positive and significant effect of $1 \%$, compared to traditional (manual) production.

Keyswords: Crushing machine, Cameroon, impact analysis, income, producers, Ricinodendron heudelotii

How to cite this article: Biloa, T.F., Bernard, K.M.C., André, N.N. Rene, M.N.J. and Abdon, A. 2021. Impact Analysis of an Innovative Extraction Process for Ndjansang (Ricinodendron heudelotii) Seeds on the Welfare of Local Producers in Nyong and Mfoumou Division, Cameroon. IJAEB, 14(03): 475-483.

Source of Support: None; Conflict of Interest: None 
The Congo basin with his 200 million hectares of forest is the second largest forest massif on the planet (Vernière et al. 2020; Atyi et al. 2013). This forest set comprises Timber Forest Products (TFPs) and Non-Timber Forest Products (NTFPs). NTFPs provide various functions such as the supply of food and medicine for local populations, materials and energy for industry, but above all, it is an important source of income for households (Djeugap et al. 2013; Tata and Awono 2014). Thus, they constitute an effective means of addressing poverty and also contribute to increasing the local economy's level (Awono et al. 2016). Among these NTFPs, Ndjansang (Ricinodendron heudelotii) is the most essential product. With a percentage of consumption estimated at more than $70 \%$, it is one of the preferred species in the Cameroonian wetland (Ayuk et al. 1999; Tata and Awono 2014). Its almonds are very appreciated in the food and are the object of important marketing (Ayuk et al. 1999). Indeed, according to Atyi et al. (2013), its annual turnover in 2010 was estimated at 365 million FCFA. Since this period, the economic value of Ndjansang has been growing steadily in recent years, to the point where its average price has tripled, reaching almost double that of cocoa. Furthermore, with an average annual income of more than 12 million FCFA in 2014 , it has risen from $4^{\text {th }}$ to $3^{\text {rd }}$ place in economic value and use (Tata and Awono 2014).

In terms of its advantages, Heudelotti Ricinodendron has a high nutritional value, making it a safe ally in preserving food safety. It contains per $100 \mathrm{~g}$ of wet almonds, $530 \mathrm{Kcal}$ equivalent to $21.2 \mathrm{~g}$ of Proteins, $43.1 \mathrm{~g}$ of Fat, $23.4 \mathrm{~g}$ of carbohydrates, $611 \mathrm{mg}$ of Calcium, $0.4 \mathrm{mg}$ of Iron, and $5.5 \%$ of water (FAO, 1968). Its tree, which can reach $40 \mathrm{~m}$ in length and $1.2 \mathrm{~m}$ in diameter, provides shade for crops in agricultural areas and humans and livestock. With its roots populated with mycorrhizae, fungi that grow symbiotically with the roots act as natural manure. Rural populations also use the seeds also use the seeds to take several medicines. In particular in the treatment of female infertility, child fever, and as appetite stimulant. The bark is used against venereal diseases such as gonorrhea. They treat diarrhea, cough, dysentery, rheumatism, rickets in children, oedema; elephantiasis; fungus; painful menstruation; and to prevent abortion; to soothe the pains of pregnancy; to give strength to premature newborns; and to ripen abscesses, boils, and bubbles. The roots can be used as an aphrodisiac. In cosmetics, Ricinodendron heudelotii fine is used in soap and varnish factories due to its high oil content.

Despite its importance, both at the national and household economic level (Nkwatoh et al. 2011; Nkwatoh and Yinda 2007), the study of (Caspa et al. 2018), have revealed the existence of certain production constraints related to the distance between collection points and villages, seasonality and processing difficulties. In addition, the increasing number of producers is leading to intense pressure on the resource, with a consequent drop in the productivity of trees on the periphery of these villages. Moreover, as not everyone has the opportunity to have a Ndjansang tree, producers are forced to travel miles through the forest to find one. After harvesting the green fruits, they go through the rotting phase for a few days to facilitate their extraction. Each green fruit, containing about 3 black seeds (Fig. 1), is then dried and broken in a rudimentary way (either with stones or with a flattened nail) which can cause many breakages and make the seeds unsuitable for sale. This process takes much time, and thus deprives households of their everyday activities. The drying phase is also very tedious, as the extracted almonds are dried in full sun, sometimes during the rainy season, which is not always easy.

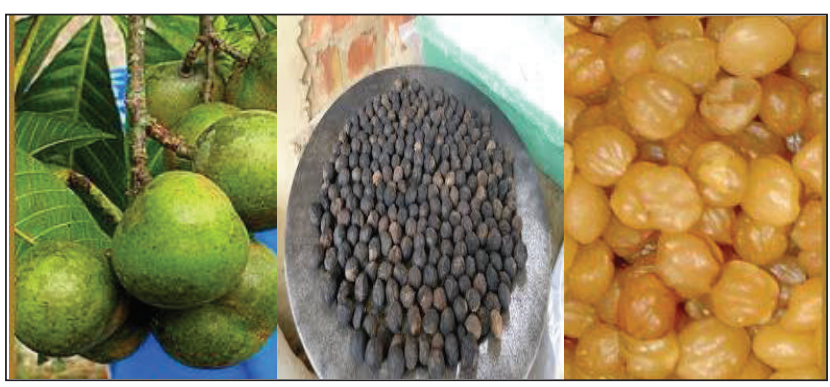

Source: Authors.

Fig. 1: Different stages in the production of Ndjanssang Almonds

This research on constraints in the Ndjansang sector was developed to signify the vital contribution of this NTFP in the lives of grassroots populations. According to Ndumbe et al. (2019), seasonality, storage, and processing influence the price of agricultural products. As far as the processing of Ndjansang is concerned, the main aim is to produce 
vegetable oil which, due to its content of vitamins E, B, D, B9, and omega 3, has antioxidant, anticholesterol, and anti-aging properties for the skin (source). The extraction of this product is very laborious, as it requires large quantities of seeds for little oil. However, this very virtuous oil remains unaffordable for a specific category of consumers, discouraging rural producers who specialize in its production. Although the composition of some spice blends in manufactured products contains Ndjansang, household demand for processing Ndjansang almonds into pure paste or powder remains very high. Hence the need for innovation in processing. Therefore, processing Ndjansang in particular, particularly isime-consuming (Caspa et al. 2018). Improving the efficiency of post-harvest seed extraction work seems, therefore, to be an essential concern. Indeed, the time difference in the seed production process shows an overall time saving between innovative and traditional extraction techniques. This difficulty is characterized by the lack of agricultural innovations such as crushing machines for some rural producers (Mbosso et al. 2013); Endamana et al. 2016; Suleiman et al. 2017). As for most Cameroonian farmers, Ndjansang producers do not always benefit from several innovations appropriate to their farming systems; which would allow them to increase their productivity and income (Alizadeh 2011). The crushing machine (Fig. 2) introduced here in each intervention village is a technological innovation that consists of the mechanization of the crushing process. With a value of US \$3500, its production capacity used in an optimal way ( 8 hours/day) is $600 \mathrm{Kg}$. Its access remains free for members of the farmers' organization and is conditioned by direct costs of US \$ 2 for $15 \mathrm{Kg}$ of crushed almonds for non-members.

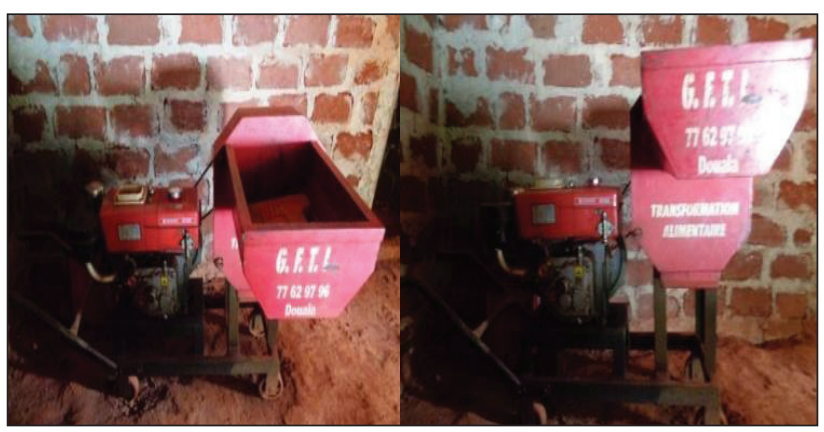

Source: Authors

Fig. 2: Ndjansang crushing machine
Improving the productive efficiency of Ndjansang almonds and income requires the implementation and dissemination of new technologies to local producers (Mbosso et al. 2013).

Indeed, a package of innovations has been introduced in Nyong and Mfoumou, including creating a farmers' organization, the domestication of Ndjansang, market information systems, group sales, and the seed crushing machine. Membership in the farmers' organization serves as a pass for other innovations where appropriate. However, we chose the seed crushing machine for this study because of its technical specificity and productivity advantages. With this in mind, this seed crushing machine has been designed and introduced in some rural areas in Cameroon to provide an alternative to a manual extraction and thus reduce the drudgery of the production activity. Therefore, the objective of this article is to assess the impact of the Ndjansang almond crushing machine on the welfare of Ndjanssang producers in Cameroon. Specifically, it is a question of measuring the contribution to the improvement of income levels of the Nyong and Mfoumou division Centre region Cameroon producers.

\section{MATERIALS AND METHODS}

\section{Study area}

The Nyong and Mfoumou is a division located in the central region of Cameroon. The division covers an area of $6172 \mathrm{~km}^{2}$ for a population of 130321,43 . The landform consists of plateaus, hills, and slopes. The Nyong and Mfoumou rivers are the main water streams that make up its hydrography and are at the origin of its name. The principal economic activities here are commercializing agricultural products such as cocoa, coffee, plantain, palm oil, sweet potato cassava, and yam. The most represented ethnic groups are the Yebekolo, Mbidabani, Yembama, Mvog Nyengue, Yengono, Yenono, Omvang , etc. They constitute a dynamic labor force that guarantees the high agricultural productivity of the Division. However, the landlockement of certain rural production areas constitutes a significant constraint of the development of this Division.

\section{Data sources and Processing technics}

This study was conducted in Nyong and Mfoumou 
division, where a sample of 216 farmers from Ndjansang was selected in a stratified manner, with 116 producers in the villages of Ekpwassong, Ondeck, and Ebassi constituting the intervention villages on the one hand, and 100 in Nyamvoudou, Abam-Yendjock and Akolo villages which are the control villages on the other hand. Intervention villages refer to those who have adopted the innovation of the crushing machine, and control villages refer to those who haven't adopted it and haven't heard about it. It essentially consists of primary data of socio-demographic types (age, gender group membership etc.), agricultural (area, total production, yield etc.), and producers' adoption of a crushing machine. The collection technic included semi-structured interviews and participatory observations that were tested for data robustness.

\section{The structure of propensity score matching}

The welfare indicator used to observe the impact of the crushing machine's adoption is the Ndjanssang producer's income. Thus, to assess this impact, we compare the Ndjanssang producers who adopt the crushing machine as innovation and those who do not in the Nyong and Mfoumou Division in Cameroon central region. For this, we'll use the propensity score-matching method proposed by (Rubin 2006). This technique consists of constructing a statistical comparison group based on the probability of adopting the machine such that:

$$
P(X)=(T=1 / X)
$$

With $T_{i}$ the decision to adopt the machine such as:

$$
T_{i}=\left\{\begin{array}{l}
i=1 \text { if the producer adopts the crushing machine } \\
i=0 \text { if not }
\end{array} .\right.
$$

The treatment effect is captured by canceling out differences in individual characteristics and treatment in the two groups. Descriptive statistics will allow us to characterize our sample and the treatment (which adopts the crushing machine) and control (which does not adopt it) groups.

\section{Estimation method}

The average effect of the treatment on treaties is such that:

$$
\begin{aligned}
& \Delta_{A T T}=E\left(Y_{T}-Y_{N T} \mid 1\right) \\
& =E[Y-E(Y \mid X, T=0) \mid T=1] \\
& =\left[E\left(Y_{T} \mid T=1, X={ }_{X}\right)-E\left(Y_{N T} \mid X, T=0, X={ }_{X}\right)\right]
\end{aligned}
$$

The estimator $\Delta_{A T T}$ is the average of the deviations of the treaty status and the counter-factual. Therefore, it is necessary to estimate $E\left(Y_{N T} X=x_{i^{\prime}} T=0\right)=$ $f\left(X_{i}\right)$, for each individual treated as a characteristic $X_{i}$. To achieve this, it is essential to match on the basis of the propensity score and to ensure that the means of the outcome variable of the two groups are statistically different. Our estimation sequence is therefore as follows:

- We estimate the propensity score (PS) or probability of adopting the crushing machine from a Probit or Logit model and calculate the marginal effects;

- We perform a statistical difference test of the means of incomes of the two groups;

- We determine the joint support by the Kernel parametric regression suggested by Heckman et al. (1998) and the nearest five 'neighbour's method;

- Finally, we calculate the standard deviation of the estimator by the Bootstrap method.

\section{RESULTS}

\section{Socio-economic characteristics of producers}

The purpose here is to describe the innovation diffusion process that has been implemented in the Nyong and Mfoumou divisions. The aim is to examine the determinants of the adoption of the crushing machine in order to assess its impact on farmers' incomes. Thus, a Ndjansang crushing machine with a value of US \$ 3500 was offered to each of the intervention villages. It had an adoption quota of 116 adopters (producers from villages that received the machine) versus 100 non-adopters (producers from villages that did not receive a machine). The various tests of the model will make it possible to determine the significance of the impact on the income of the main producers. The choice of our sample was made in a reasoned manner among the mother population of the Nyong and Mfoumou divisions. The mother population has broadly similar socioeconomic and cultural 
Table. 1: Statistical characterization of model variables

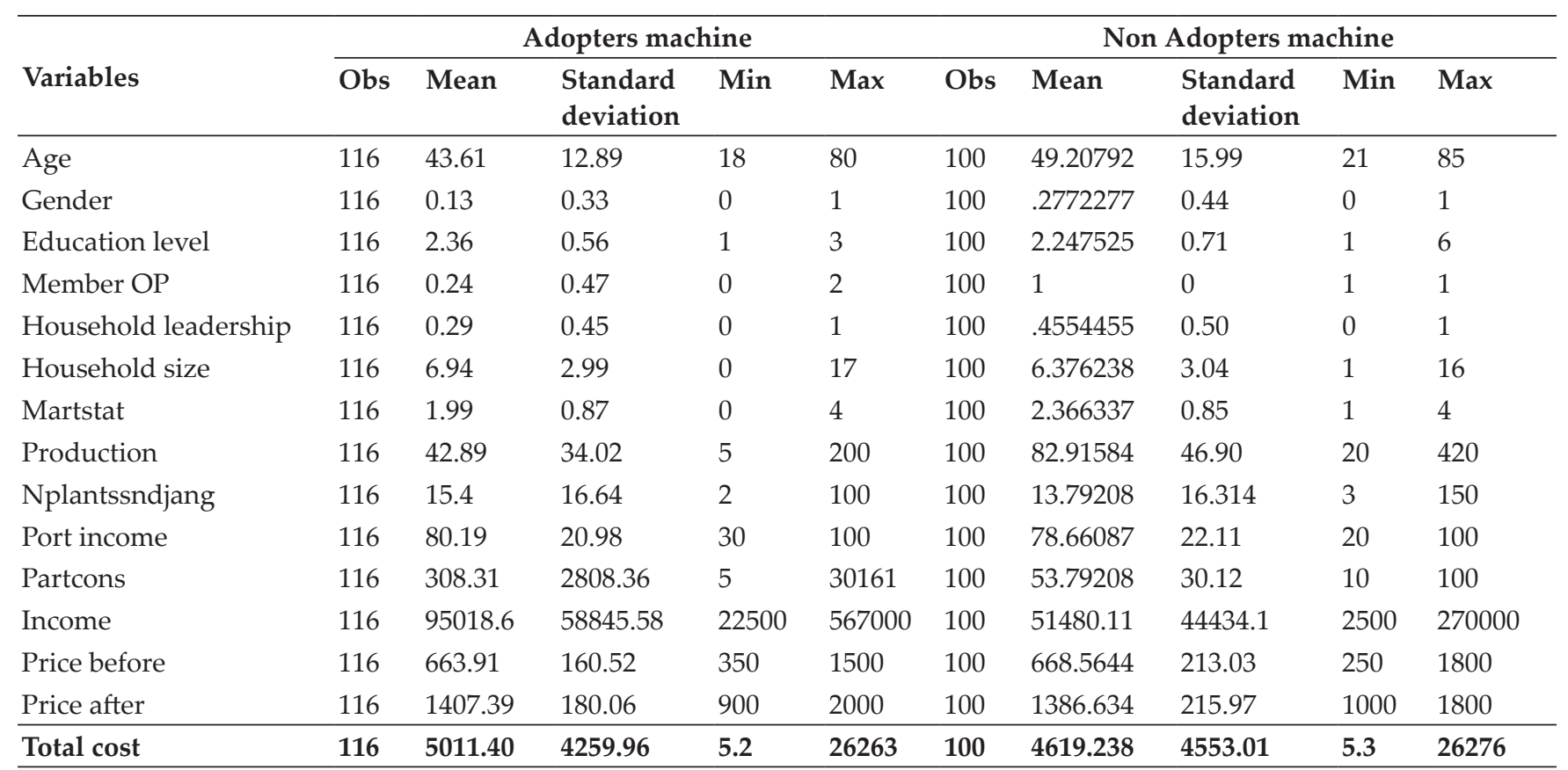

Source: Authors.

characteristics such as language, culture, farming habits, commercial activities, and many others throughout the division.

The statistical characterization aims to provide information that allows precise knowledge of the broad specificities of the producers in the sample and the determination of potential explanatory variables of the impact on farmers' income in the study area.

Table 1 provides some information on the characteristics of the two groups of producers. The average of men in all villages in the sample is higher than that of women. This is justified because the development around Ndjansang is pushing more and more men to join women in exploiting Ndjansang. Moreover, the fact that men are strongly represented than women leads to an increase in the quantities produced because men's labor force seems more efficient. The average age for each of these functional groups is between 43 and 49 years old, respectively. This age difference is explained by the fact that younger producers believe that they gain in husking time and think the quality of the husked seeds is better. The results related to marital status show a predominance of married producers with a total of 150 out of 216, compared to 33 widowers, 30 single and three divorced. This situation is explained by the fact that the vast majority of producers are at the head of family farms in the study area and thus manage the Ndjansang-related activity in the household.

Moreover, the results show that, on average, the different households have an average number of Ndjansang plants that varies between 15 for adopters and 16 for non-adopters, respectively for a total production of $42 \mathrm{Kg}$ for the first and 46 for the second group. The share of Ndjansang's income in average household income is $80 \%$ for adoptive households and only $22 \%$ for non-adopters. Such a result demonstrates the important contribution of the Ndjansang sector in reducing household food insecurity in the Nyong and Mfoumou division, especially since the total costs generated by seed production are affordable for low-income households, with US $\$ 10$ for adopting producers and US \$ 9.10 for non-adopting producers respectively.

\section{Test for comparing average incomes}

The $t$ statistic comparing the average percentage share of Ndjansang's income of adopters and nonadopters is significant at $1 \%$ (Table 2 ).

This test of comparison of averages confirms the results of the above descriptive statistical analyses. Its results show a difference between producers 
Table 2: Test for comparing averages

\begin{tabular}{llllllllllll}
\hline \multirow{2}{*}{ Variable } & \multicolumn{3}{c}{ Adopters } & \multicolumn{1}{c}{ Non Adopters } & \multicolumn{3}{c}{ Probability } \\
\cline { 2 - 12 } & Obs & Mean & Stand dev & Min & Max & Obs & Mean & Stand dev & Min & Max & \\
\hline Port income & 116 & 80.19 & 20.98 & 30 & 100 & 100 & 78.66 & 22.11 & 20 & 100 & $0.0000^{*}$ \\
\hline
\end{tabular}

Source: Authors.

who have adopted and producers who have not adopted the machine in terms of the share of income generated by Ndjansang. Significance at $1 \%$ allows the use of the propensity score matching method to reduce bias.

\section{Estimation of the probability of the propensity Score}

The Probit estimation of crushing machine adoption (Table 3) reveal that members of the peasant organization, quantities produced, household size, and the price of the Ndjansang bowl influences the probability of adopting the crushing machine. Hence the implication of the non-identity of the two sub-samples. It then becomes essential to match the two entities.

Table 3: Probit estimation of adoption determinants

\begin{tabular}{ll}
\hline Variables & Coefficients \\
\hline Member OP & $2.519^{* * *}$ \\
& $(0.352)$ \\
Household leadership & -0.0395 \\
& $(0.370)$ \\
Household size & $-0.0804^{*}$ \\
& $(0.0429)$ \\
Martstat & 0.174 \\
& $(0.191)$ \\
Production & $0.0192^{* * *}$ \\
& $(0.00466)$ \\
Port income & 0.00381 \\
Price after & $(0.00646)$ \\
& $-0.00121^{*}$ \\
Constant & $(0.000671)$ \\
& $(3.63 \mathrm{e}-05)$ \\
Observations & -1.883 \\
\hline
\end{tabular}

Source: Authors.

Standard deviation in brackets ${ }^{* * *}$ significant at 1\%; ** significant at $5 \%$; * significant at $10 \%$.

The distribution of kernel vector between the treatment and control groups (Fig. 3) shows the difference in distribution between the two groups.

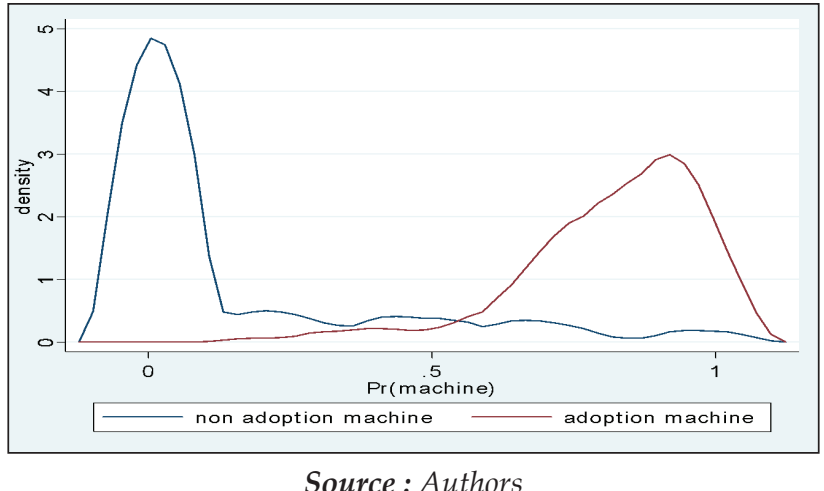

Fig. 3: Kernel density of propensity scores

Thus, between -0.15 and 0.15 , the kernel vector shows that non-adopters have a percentage of income $4.90 \%$ higher than adopters. Moreover, in the range 0.55 to 1.10 , the adoption of the crushing machine offers, contrary to the first trend, a higher share, either $3 \%$ of income, to producers who have adopted the innovation.

\section{Matching of Ndjansang producers}

Table 4 shows the significant difference across characteristics in the group of unmatched producers. Samples matched successively by the kernel and nearest 5 neighbors provide the validity of comparability required to minimize the bias but cannot entirely remove it.

Thus, even if the bias has not been completely eliminated, it has been considerably reduced so that the remaining producers present the same characteristics.

\section{Impact of the crushing machine on Ndjansang's income}

The impact indicator of the adoption of the crushing machine here is the change in the share of income in Ndjansang. This impact shows whether the adoption of the crushing machine will increase the income of Ndjansang producers. Table 5 presents the result of estimating the average effects of the adoption of the machine on Ndjansang's income. This result of the 
Table 4: Sample Matching Test

\begin{tabular}{|c|c|c|c|c|c|c|c|c|c|}
\hline \multirow{3}{*}{ Variables } & \multirow{2}{*}{\multicolumn{2}{|c|}{$\begin{array}{c}\text { Unmatched samples } \\
\text { Mean } \\
\end{array}$}} & \multirow{3}{*}{ P-value } & \multirow{2}{*}{\multicolumn{2}{|c|}{$\begin{array}{c}\begin{array}{c}\text { Matched by } \\
\text { Kernel }\end{array} \\
\text { Mean } \\
\end{array}$}} & \multirow{3}{*}{ P-value } & \multirow{2}{*}{\multicolumn{2}{|c|}{$\begin{array}{c}\text { Matched by the } 5 \text { closest } \\
\text { neighbours method }\end{array}$}} & \multirow{3}{*}{ P-value } \\
\hline & & & & & & & & & \\
\hline & Treated & Control & & Treated & Control & & Treated & Control & \\
\hline Machine & 1 & $\cdot$ & 0.000 & 1 & $\cdot$ & 0.000 & 0.000 & 0.000 & . \\
\hline Age & 49.20 & 43.61 & 38.5 & 49.37 & 43.167 & 42.7 & 2.84 & 3.39 & -11.1 \\
\hline Gender & 0.27 & .1304 & 36.9 & 0.23 & .04558 & 48.0 & 2.73 & 3.87 & -30.1 \\
\hline Edulevel & 2.24 & 2.36 & -18.3 & 2.22 & 2.5381 & -48.5 & -1.35 & -3.46 & -165.4 \\
\hline Member OP & 1 & 0.24 & 227.6 & 1 & 1.158 & -47.5 & 16.17 & -3.42 & 79.1 \\
\hline Household leadership & 0.45 & 0.29 & 33.3 & 0.43 & .14326 & 59.8 & 2.45 & 4.54 & -79.5 \\
\hline Household size & 6.37 & 6.94 & -18.9 & 6.24 & 6.4892 & -8.0 & -1.39 & -0.62 & 57.7 \\
\hline Martstat & 2.36 & 1.99 & 43.3 & 2.40 & 2.2718 & 15.8 & 3.18 & 1.12 & 63.5 \\
\hline Port income & 80.19 & 78.66 & 7.1 & 81.66 & 78.692 & 13.8 & 0.52 & 0.83 & -93.5 \\
\hline Port cons & 53.79 & 308.31 & -12.8 & 54.44 & 46.269 & 0.4 & -0.91 & 1.96 & 96.8 \\
\hline Production & 82.91 & 42.89 & 97.7 & 75.80 & 84.165 & -20.4 & 7.24 & -2.01 & 79.1 \\
\hline Nplantssndjang & 13.79 & 15.4 & -9.8 & 12.53 & 9.8793 & 16.1 & -0.71 & 2.03 & -65.3 \\
\hline Price before & 68.56 & 663.91 & 2.5 & 674.46 & 779.36 & -55.6 & 0.18 & -4.09 & -2155.2 \\
\hline Price after & 86.6 & 1407.4 & -10.4 & 1382.3 & 1538.2 & -78.5 & -0.77 & -5.13 & -651.5 \\
\hline Total cost & 19.20 & 5011.4 & -8.9 & 4477.2 & 6146.7 & -37.9 & -0.65 & -3.20 & -325.7 \\
\hline
\end{tabular}

Source: Authors.

estimation of the average effects based on Kernel and nearest five neighbors matches show that: producers who have adopted the crushing machine receive US \$ 0.16 more per $\mathrm{Kg}$ than those who have not adopted. This positive effect is statistically significant at $1 \%$ and robust across the two forms of matching. We find that the two matching methods also eliminate the bias in the group of unmatched producers to make them all similar or even identical after matching. Moreover, this result is obtained with 208 observations because eight observations of the treatment group could not be matched with the observations of the control group.

\section{DISCUSSION}

Given the arduous task of extracting almonds from Ndjansang, a crushing machine was introduced to Ndjansang producers in Nyong and Mfoumou Division. In contrast to the work of (Mbosso et al. 2015), which aimed to assess the economic value that producers attribute to this innovation, this study assesses its impact on producers' income through the propensity score matching model and on improving their livelihoods more generally. A review of evaluation methods shows that this model is best suited to this type of counter-factual analysis.
Table 5: Impact of the adoption of the machine on the income of Ndjansang producers

\begin{tabular}{|c|c|c|}
\hline Statistics & Kernel & $\begin{array}{l}5 \text { nearest } \\
\text { neighbours }\end{array}$ \\
\hline ATT & $0.16^{* * *}$ & $0.16^{* * *}$ \\
\hline Standard deviation & 9.16 & 9.16 \\
\hline $\begin{array}{l}\text { Number of observations } \\
\text { from the treated group }\end{array}$ & $101(8)$ & 101(8) \\
\hline $\begin{array}{l}\text { Number of observations } \\
\text { from control group }\end{array}$ & 115 & 115 \\
\hline
\end{tabular}

Source: Authors.

Indeed, (Ahmed et al. 2016) used this method to assess the impact of improved groundnut seeds on farmers' income in Ethiopia. However, studies such as (Abdulai 2016) use a different model, namely recursive bivariate Probit. In addition, some studies make joint use of several techniques for impact assessment. Indeed, (Khonje et al. 2015) simultaneously use propensity score matching and endogenous switching regression models to analyze the impacts of improved maize varieties on welfare in Zambia. For (Mbosso et al. 2013), the theoretical basis for the successful adoption of any innovation thus lies in technologies developed between manufacturers and users. 
Regarding adoption factors, our results show that membership of the producer organization, household size, output, and price before innovation are the main determinants that significantly explain the adoption of the crushing machine. Agricultural liberalization has contributed to the establishment of POs. These organizations intervene with producers through certain services to guarantee their welfare. The membership of a PO is thus an important determinant for the well-being of producers. In fact, (Nde-Atse 2009) also estimates whether or not the head of household belongs to a PO explains the adoption behavior of an innovation. The purchase price of the Ndjansang after the innovation has been established as a determining factor that can motivate producers to choose mechanical extraction and improve their perception of the innovation.

Our analyses also revealed that with the adoption of the machine, some adopters have a higher average income share than the adopters. This is explained on the one hand by the fact that the extension of group sales in the intervention villages has contributed to the increase in the price of sales in the area, but also that the ease and flexibility of mechanical extraction work have promoted labor efficiency and attributed some additional benefits to small local producers. Among other things, the results of the estimation of average effects based on kernel and nearest five neighbors pairings show that producers who adopt the machine improve their income and thus their welfare. This result is in line with those of (Kamdem 2014), which reveals that collective marketing has a statistically significant and positive effect on the net price received by producers. This improves their income by US \$ 0.066 per kilogram of cocoa sold collectively, representing a $6 \%$ increase in the price for individual sales. Among others, (Simtowe et al. 2012) also find a significant positive impact of adopting the new groundnut variety on the purchasing power of 594 households and the reduction of poverty indices. However, some work shows that adopting innovation does not always lead to improved income and thus welfare. For example, (Alamgir Hossain and Crouch 1992), evaluating the adoption of improved rice varieties in Bangladesh showed that adoption negatively impacts poor households.

\section{CONCLUSION}

Non-timber forest products such as Ndjansang still represent an important income and food security resource for households in the Cameroon, particularly for the people of Nyong and Mfoumou in the country's central region. This article on the adoption of an Ndjansang almonds crushing machine aimed to assess the effect on producers' income based on propensity score matching method and on their welfare. The results reveal a significant increase in the adoption of this innovation. Indeed, with an amount of US \$ 0.16 per Kg produced, producers who adopt the innovation improve income compared to non-adopters. This income thus enables them to improve their diet by purchasing foodstuffs such as fish and cereals. They also have the capacity, through this increase in income, to improve their health care.

Moreover, producers who adopt the innovation also improve their livelihood. Indeed, the crushing machine allows households to have more time for family relaxation through recreational evenings; their children who are part of the labor force have more time for studying their lessons. Although small, this income difference confirms the hypothesis that agricultural innovation positively affects the welfare of producers in the study area. Nevertheless, the difference in results related to the use of the machine from one village to another raises questions about the success of technology transfer and adoption by rural producers. It would thus be essential to introduce and disseminate this innovation through valuation policies in the Ndjansang value chain to ensure a continuous improvement in producers' incomes. Also, it will be essential to plan a co-constructed reorganization of the various actors. They must intervene in implementing this innovation according to the various links of the value chain of the Ndjansang value chain.

\section{ACKNOWLEDGMENTS}

The authors are grateful to all the Ndjansang's producers in the villages of Ekpwassong, Ondeck, Ebassi, Nyamvoudou, Abam-Yendjock, and Akolo in Nyong and Mfoumou division, for providing all the information in order to facilitate the achievement of this research. 


\section{REFERENCES}

Abdulai, Abdul Nafeo. 2016. "Impact of Conservation Agriculture Technology on Household Welfare in Zambia." Agric. Econ., 47 (6): 729-41.

Ahmed, Musa H., Hiwot M. Mesfin, Seltene Abady, Wendmagegn Mesfin, and Amare Kebede. 2016. "Adoption of Improved Groundnut Seed and its Impact on Rural 'Households' Welfare in Eastern Ethiopia." Edited by Goodness Aye. Cogent Econ. Finance, 4(1).

Alamgir Hossain, Shah M. and Bruce R. Crouch. 1992. "Patterns and Determinants of Adoption of Farm Practices: Some Evidence from Bangladesh." Agric. Sys., 38 (1): 1-15.

Alizadeh, Mohammad Reza. 2011. “Effect of Paddy Husked Ratio on Rice Breakage and Whiteness during Milling Process." Aust. J. Crop Sci., 5(5): 562-65.

Atyi, Richard Eba'a, Guillaume Lescuyer, Jonas Ngouhouo Poufoun, and Thérèse Moulendè Fouda. 2013. “Étude de l'importance économique et sociale du secteur forestier et faunique au Cameroun." Rapport final. Cameroun: CIFOR.

Awono, A, R'Eba'a Atyi, Tita Foundjem, and P Levang. 2016. "Vegetal Non-Timber Forest Products in Cameroon, Contribution to the National Economy." Int. for Rev., 18(1): 66-77.

Ayuk, Elias T., Bahiru Duguma, Steve Franzel, Joseph Kengue, Matthias Mollet, Theophile Tiki-Manga, and Pauline Zenkeng. 1999. “Uses, Management and Economic Potential of Garcinia Kola and Ricinodendron Heudeloth in the Humid Lowlands of Cameroon." J. Trop. for Sci., 11(4): 746-61.

Caspa, R.G., Tchouamo, I.R., Mate Mweru, J.-P. and Amang Mbang, J. 2018. “Marketing Ricinodendron heudelotii Kernels and Gnetum spp. Leaves Around Lobeke National Park, East Cameroon." Tropicultura, 36(3): 565-77.

Djeugap, F.j, L Bernier, D Dostaler, D Khasa, Da Fontem, and D Nwaga. 2013. “Opportunités et contraintes agroforestières de Ricinodendron heudelotii au Cameroun." Int. J. Biol. Chem. Sci., 7(1): 344.

Endamana, D., K.A. Angu, G.N Akwah, G. Shepherd, and B.C. Ntumwel. 2016. “Contribution of Non-Timber Forest Products to Cash and Non-Cash Income of Remote Forest Communities in Central Africa." Int. for Rev., 18(3): 280-95.

Icard-Vernière, C., E. Martorell, V. Vaissayre, S. Dussert, C. Picq, H. Womeni, and C. Mouquet-Rivier. 2020. "Le Safou, Un Atout Nutritionnel Dans La Diète Des Camerounais." Nutrition Clinique et Métabolisme, 34(1): 33-34.

Kamdem, CyrilleBergaly. 2014. “Impact de la commercialisation collective par les organisations paysannes sur le prix au producteur du cacao au Cameroun." In 8es Journées de Recherches en Sciences Sociales - 11-12 décembre 2014, 37. Grenoble.
Khonje, Makaiko, Julius Manda, Arega D. Alene, and Menale Kassie. 2015. "Analysis of Adoption and Impacts of Improved Maize Varieties in Eastern Zambia." World Dev., 66: 695-706.

Mbosso, Charlie, Ann Degrande, Patrick Tabougue, Steven Franzel, Patrick Van Damme, Zac Tchoundjeu Zac, and Divine Foundjem-Tita. 2013. “No Appropriate Technology so Far for Ricinodendron heudelotii (Baill. Pierre Ex Pax) Processing in Cameroon: Performance of Mechanized Kernel Extraction." Afr. J. Agric. Res., 8(46): 5741-51.

Mbosso, Charlie, Ann Degrande, Grace B. Villamor, Patrick Van Damme, Zac Tchoundjeu, and Sygnola Tsafack. 2015. "Factors Affecting the Adoption of Agricultural Innovation: The Case of a Ricinodendron heudelotii Kernel Extraction Machine in Southern Cameroon." Agrofor. Syst., 89(5): 799-811.

Nde-Atse, Hp. 2009. “Facteurs D'adoption De Varietes Ameliorees De Riz En Côte D'ivoire : Cas De La Region De Korhogo." Agron. Afr., 19(1).

Ndumbe, Louis Njie, Verina Ingram, Martin Tchamba, and Smith Nya. 2019. “From Trees to Money: The Contribution of Njansang (Ricinodendron heudelotii) Products to Value Chain 'Stakeholders' Financial Assets in the South West Region of Cameroon." For Trees Livelihoods, 28(1): 52-67.

Nkwatoh, A.F., Labode, P., Ebobenow, L., Nkwatoh, F.W., Ndumbe, N.L. and Ewane, M.E 2011. “Gathering, Processing and Marketing of Ricinodendron Species (Baill) in the Humid Forest Zone of Cameroon." Agric. Sci. Res. J., 1(9): 213-21.

Nkwatoh, A.F. and Yinda, G.S. 2007. “Assessment of NonTimber Forest Products (NTFPs) of Economic Potentials in the Korup National Park, of South Western Cameroon." Global J. Agric. Sci., 6(1).

Rubin, D. 2006. "Matched Sampling for Causal Effects." Matched Sampling for Causal Effects, January. https://doi. org/10.1017/CBO9780511810725.

Simtowe, Franklin, Menale Kassie, Solomon Asfaw, Bekele A Shiferaw, Emmanuel Monyo, and Moses Siambi. 2012. "Welfare Effects of Agricultural Technology Adoption: The Case of Improved Groundnut Varieties in Rural Malawi."

Suleiman, Muhammad Sabiu, Vivian Oliver Wasonga, Judith Syombua Mbau, Aminu Suleiman, and Yazan Ahmed Elhadi. 2017. "Non-Timber Forest Products and Their Contribution to Households Income around Falgore Game Reserve in Kano, Nigeria." Ecol. Process, 6(1).

Tata, P. and Abdon, A. 2014. “Enquêtes Socio-Économiques Sur Les Filières Mangue Sauvage, Ndjansan et Okok Au Cameroun." Programmes et Politiques de Gestion Des Ressources Naturelles Axés Sur Les Produits Forestiers Non Ligneux (PFNL) En Afrique de l'Ouest et Du Centre, Projet PFNL-4P. Cameroun: CIFOR/IRAD. 
